\title{
IMPLEMENTASI DETEKSI TEPI UNTUK MENDETEKSI KERETAKAN TULANG ORANG LANJUT USIA (MANULA) PADA CITRA RONTGEN DENGAN OPERATOR SOBEL DAN PREWITT
}

\section{Implementation Of Edge Detection For Detecting Elderly Bone cracked In Rontgen Images With Sobel And Prewitt Operators}

\author{
I Gusti Ngurah Suryantara, gusti@bundamulia.ac.id ${ }^{1)}$ \\ ${ }^{1)}$ Teknik Informatika / Fakultas Teknologi dan Desain, Universitas Bunda Mulia
}

\begin{abstract}
Digital images today are very useful in all fields, digital images are needed by users for analysis and decision making. Various image analyzes are used to produce output images according to needs. The use of filters on input images is one of the methods used to produce output images as needed. In this study, an image processing application uses Sobel and Prewitt filters. Filter Sobel and Prewitt to produce edges in the image. Edge detection in images can be implemented in medical fields, such as analysis of bone fractures. Broken bones create edges, cracked parts are reinforced with Sobel and Prewitt filters. What was done in this study were: literature study, the application of the Sobel and Prewitt filters. Next, analyze and design image processing applications with sobel and prewitt filters. In this study using Sobel and Prewitt filters to strengthen the edges of the input image. By using these two fiter, it can display the edge of the image for analysis by the user.
\end{abstract}

Keywords: Image, Digital Image, Sobel Filter, Prewitt Filter, Edge.

\begin{abstract}
ABSTRAK
Citra digital sekarang ini sangat bermanfaat dalam segala bidang, citra digital dibutuhkan oleh pengguna untuk analisis dan mengambil keputusan. Berbagai analisis citra digunakan untuk menghasilkan citra keluaran sesuai dengan kebutuhan. Penggunaan filter pada citra masukan merupakan salah satu cara yang digunakan untuk menghasilkan citra keluaran sesuai kebutuhan. Pada penelitian ini membuat aplikasi pengolahan citra menggunakan filter Sobel dan Prewitt. Filter Sobel dan Prewitt untuk menghasilkan tepi pada citra. Deteksi tepi pada citra bisa diimplementasikan pada bidang medis, seperti analisis keretakan pada tulang. Keretakan pada tulang menciptakan tepi, bagian yang retak diperkuat dengan filter Sobel dan Prewitt. Yang dilakukan dalam penelitian ini adalah: studi pustaka, penerapan filter Sobel dan Prewitt. Selanjutnya melakukan analisis dan desain aplikasi pengolahan citra dengan filter sobel dan prewitt. Pada penelitian ini menggunakan filter Sobel dan Prewitt untuk memperkuat tepi pada citra masukan. Dengan menggunakan dua fiter ini sudah bisa menampilkan tepi pada citra untuk analisis oleh pengguna.
\end{abstract}

Kata Kunci: Citra, Citra Digital, Filter Sobel, Filter Prewitt, Tepi

Citra digital sebagai keluaran dari pengolahan citra dewasa ini sangat di butuhkan pada era digital dewasa ini. Pada penelitian ini dikembangkan dari teori-teori pengolahan citra digital mengenai deteksi tepi (edge detection) dengan filter Sobel dan filter Prewitt untuk mendapatkan tepi dari suatu citra dari sumbu $\mathrm{X}$ dan $\mathrm{Y}$.
Sehingga tepi-tepi dari citra dari sumbu $\mathrm{X}$ dan Y dapat dipertegas untuk mendapatkan citra keluaran sebagai dasar analisis lebih lanjut oleh pengguna data di dalam pengambilan suatu kesimpulan.

Pengolahan citra digital mengalami kemajuan penting dalam bidang kodokteran 
ketika ditemukan tomografi

terkomputerisasi (Computerized

Tomography/CT) pada tahun 1990-an dan

kini teknologi tomografi tersebut sudah maju sangat pesat.

Pengolahan citra digital dewasa ini dapat diterapkan di berbagai bidang seperti:

- Pada industri film: untuk menghaluskan gambar, untuk menajamkan gambar, memberikan visual efek, dan lain sebagainya.

- Pada bidang fotografi: Dapat memberikan efek untuk: menghilangkan gangguan citra (noise), membuat foto hitam putih, membuat negative film, mempertajam tingkat keabuan citra, dan lain sebaginya.

- Bidang kedokteran, pengolahan citra juga diterapkan pada bidang kedokteran. Seperti untuk mempertajam hasil $\mathrm{x}$-ray atau hasil dari CT-Scan, dan sebagainya.

- Pada bidang komunikasi: pengolahan citra dapat di gunakan untuk memperjelas foto citra satelit untuk permukaan bumi, atau foto planetpalanet lain dari satelit penelitian.

- Pada keamanan data: data-data yang sangat penting perlu diamankan sehingga tidak mudah di salah gunakan oleh pihak-pihak yang tidak bertanggung jawab. Dapat digunakan untuk proteksi hak cipta dengan menggunakan steganografi, watermark.

- Pengenalan Pola: pengolahan citra digunakan untuk pengenalan pola, misalkan pengenalan sidik jari, retina mata, wajah, dan lain sebagainya.

- Dan masih banyak penerapan pengolahan citra pada bidang lainnya.

Pengolahan citra digital dapat digunakan untuk deteksi tomor atau kanker Rahim, identifikasi penyakit paru-paru, identifikasi penyakit hati, identifikasi penyakit tulang, segmentasi tulang dari otot yang lainnya, klasifikasi gigi, dan analisis citra mikroskopis. Beberapa dari kemajuan pada bidang kedokteran tersebut karena kemampuan pengolahan citra digital mampu menginterpretasikan sinar $\mathrm{x}$ ( $\mathrm{x}$ ray). (Putra, 2010).

\section{Latar Belakang}

Dalam pengertian yang umum citra adalah gambar. Dalam pengertian yang lebih khusus citra adalah gambar visual mengenai suatu objek atau beberapa objek. Tentu saja, wujud citra dapat bermacammacam, dari foto orang, gambar awan, hasil rontgen, hingga citra satelit. (Kadir, 2013).

Citra dibagi menjadi dua jenis, yaitu citra analog dan citra digital. Citra analog dijumpai pada kertas (misalnya foto mahasiswa di kartu mahasiswa) atau media lain seperti film rontgen. Citra adalah: citra yang dinyatakan dalam kumpulan data digital dan dapat diproses oleh komputer. (Kadir, 2013).

Citra digital pada abad informasi sekarang ini merupakan suatu data yang sangat berharga (Bhat, 2014). Citra adalah metode untuk mengubah gambar menjadi bentuk digital dan melakukan beberapa operasi (Kavita, dkk 2013). Data citra digital digunakan pada berbagai bidang, pendidikan, industri, hiburan, kesehatan, pertahanan negara, dan lain sebagainya. Untuk mendapatkan kualitas citra yang baik maka diperlukan berbagai proses, dari proses citra yang sederhana sampai dengan proses citra yang rumit. Untuk analisis citra yang rumit banyak menggunakan nilai filter sesuai dengan kebutuhannya.

Citra masukan akan dikenakan proses digitalisasi, selanjutnya dari proses digitalisasi akan dilakukan proses filtering sesuai dengan filter yang di gunakan (Tania dan Rowaida, 2016). Dalam penelitian ini mengunakan filter Sobel dan filter Prewitt (Srishti et all, 2016) untuk mendapatan tepi 
dari citra masukan menjadi citra keluaran. Tujuan mendapatkan tepi-tepi dari citra masukan adalah untuk meningkatkan garis pada citra masukan menjadi citra keluaran (Patidar dkk, 2014).

Pada penelitian ini menggunakan filter Sobel dan filter Prewitt (Adlakha, et all, 2016) untuk mendapatkan tepi dari citra masukan dan mendapatkan citra keluaran sesuai dengan nilai filter yang dikenakan pada citra masukan. Citra keluaran ini yang nantinya sebagai bahan analisis dalam pengambilan suatu kesimpulan.

Dalam pengertian yang umum citra adalah gambar. Dalam pengertian yang lebih khusus citra adalah gambar visual mengenai suatu objek atau beberapa objek. Tentu saja, wujud citra dapat bermacammacam, dari foto orang, gambar awan, hasil rontgen, hingga citra satelit. (Kadir, 2013).

Citra dibagi menjadi dua jenis, yaitu citra analog dan citra digital. Citra analog dijumpai pada kertas (misalnya foto mahasiswa di kartu mahasiswa) atau media lain seperti film rontgen. Citra adalah: citra yang dinyatakan dalam kumpulan data digital dan dapat diproses oleh komputer. (Kadir, 2013).

Citra sebagai keluaran suatu sistem perekaman data dapat bersifat optik berupa foto, bersifat analog berupa sinyal-sinyal video seperti gambar pada monitor televisi, atau bersifat digital yang dapat langsung disimpan pada suatu pita magnetik (alat penyimpan data). Menurut presisi yang digunakan untuk menyatakan titik-titik koordinat pada domain spasial atau bidang dan untuk menyatakan nilai keabuan atau warna suatu citra, maka secara teoritis citra dapat dikelompokkan menjadi empat kelas citra, yaitu: citra kontinu-kontinu, kontinudiskrit, diskrit-kontinu, dan diskrit-diskrit di mana label pertama menyatakan presisi dari titik-titik koordinat pada bidang citra sedangkan label kedua menyatakan presisi nilai keabuan atau warna kontinu dinyatakan dengan presisi angka tak terhingga, sedangkan diskrit dinyatakan dengan presisi angka terhingga. (Murni, 1992).

Secara umum, pengolahan citra digital menunjuk pada pemrosesan gambar 2 dimensi menggunakan komputer. Dalam konteks yang lebih luas, pengolahan citra digital mengacu pada pemrosesan setiap data 2 dimensi. Citra digital merupakan sebuah larik (array) yang berisi nilai-nilai real maupun komplek yang direpresentasikan dengan deretan bit tertentu. (Putra, 2010).

Sebuah citra dapat didefinisikan sebagai fungsi $f(x, y)$ berukuran $M$ baris dan $\mathrm{N}$ kolom, dengan $\mathrm{x}$ dan $\mathrm{y}$ adalah koordinat spasial, dan amplitude $\mathrm{f}$ di titik koordinat $(\mathrm{x}, \mathrm{y})$ dinamakan intensitas atau tingkat keabuan dari citra pada titik tersebut. Apabila nilai $\mathrm{x}, \mathrm{y}$, dan nilai ampllitudo $\mathrm{f}$ secara keseluruhan berhingga (finite) dan bernilai diskrit maka dapat dikatakan bahwa citra tersebut adalah citra digital. (Putra, 2010). Fungsi $f(x, y)$ seperti pada Gambar 1.

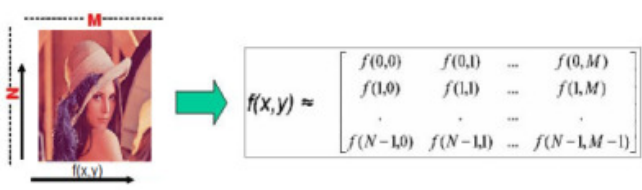

\section{Gambar 1. Koordinat citra digital $f(x, y)$}

Karakteristik operasi pada pengolahan citra berdasarkan keterlibatan piksel pada citra dapat dibagi mejadi 4 golongan, yaitu: operasi tingkat titik, tingkat lokal, operasi tingkat gelobal, dan operasi tingkat objek.

1. Operasi tingkat titik, adalah operasi piksel pada suatu koordinat yang tidak tergantung pada piksel-piksel tetangganya. Nilai keluarannya hanya tergantung nilai-nilai yang dimiliki piksel itu sendiri.

2. Operasi tingkat lokal, adalah operasi piksel pada suat koordinat yang 
tergantung pada piksel-piksel tetangganya.

3. Operasi tingkat gelobal, adalah: operasi piksel pada suatu koordinat yang tergantung pada nilai-nilai piksel yang tergantung pada keseluruhan citra.

4. Operasi tingkat objek, adalah: operasi yang dilakukan pada piksel-piksel yang dikenali apaupun akan dikenali sebagai suatu objek. Operasi ini hanya dapat dilakukan setelah pengolahan citra melewati proses segmentasi citra.

Komponen pengolahan citra digital secara umum terdiri dari pencahayaan, objek, sensor citra, komputer, media penyimpnanan dan piranti keluaran. Citra analog dari objek yang terkena cahaya ditangkap dengan kamera, citra analog yang tertangkap kamera akan diubah menjadi citra digital melalui proses sampling dan kuantisasi, citra digital disimpan pada media penyimpanan untuk nantinya dapat diolah. Hasil pengolahan citra dapat ditampilkan pada monitor, di cetak disimpan lagi untuk keperluan lain.

Proses akuisisi citra tidak terlepas dari peran sebuah komponen kecil di dalam piranti sensor citra yang photodiode. Photodiaoda adalah sebuah semikonduktor yang mengubah cahaya menjadi arus listrik. Arus listrik dihasilkan dari photon yang diserap ke photodiode. Dalam gelap nilai tahannya sengat besar hingga tidak ada arus yang mengalir. Semakin kuat cahaya yang jatuh pada diode maka makin kecil nilai tahannya, sehingga arus yang mengalir semakin besar. Terbuat dari bahan semikonduktor. Misalkan silicon ( $\mathrm{Si}$ ) atau gallium arsenide (GaAs), termasuk indium antimonide (InSb), indium arsenide (InAs), led selenide $(\mathrm{PbSe})$, dan timah sulfide (PBS) dsb. Bahan-bahan ini menyerap cahaya melalui karakteristik jangkauan panjang gelombang, misalnya: $250 \mathrm{~nm}$ ke
1100 untuk nm silicon, dan $800 \mathrm{~nm}$ ke 2,0 $\mu \mathrm{m}$ untuk GaAs. (sumber: Wikipedia).

Pembentukan citra digital dimulai dari akuisisi citra, citra ditangkap oleh sensor citra, dan oleh sensor citra di sampling berdasarkan tingkat kerapatan sampling-nya.

Semakin besar tingkat kerapatan media sampling, dalam hal ini adalah matriks bitmap, maka semakin baik citra yang dihasilkan. Hal ini tergantung pada resolusi dari komponen sensor citra yang dimiliki. Setelah penentuan piksel, maka berikutnya adalah menentukan warna yang mengisi piksel hasil sampling. Dalam hal ini peranan kedalaman bit akan sangat mempengaruhi proses kuantisasi, semakin besar jumlah bit, maka akan semakin bervariasi nilai warna yang dihasilkan, dan akan semakin lebih mirip dengan warna objek (objek aslinya).

Layar monitor tempat menampilkan citra merupakan kumpulan dari piksel. Piksel-piksel ini menyala sesuai dengan spektrum warna RGB yang dipancarkan pada bidang piksel sesuai dengan gambar yang akan ditampilkan. Resolusi merupakan ukuran kerapan suatu citra, terdapat dua macam persepsi resolusi, yaitu resolusi spasial dan resolusi kecemerlangan. Resolusi spasial dikenal dengan dpi (dot per inch), yaitu jumlah titik (piksel) per inchi. Resolusi kecermerlangan dikenal sebagai bit depth atau kedalaman bit, ini berhubungan dengan ukuran halus kasarnya pembagian tingkat gradasi warna pada saat kuantisasi. Contoh:

1. Bit depth $=1$, hanya ada gradasi $21=2$ warna, rentang nilai 0 dan 1 .

2. Bit depth $=2$, gradasi $22=4$ warna, rentang nilai $0,1,2$, dan 3 .

3. Bit depth $=8$. Gardasi $28=256$ warna, rentang nilai 0 sampai 255. 
4. Semakin tinggi resolusi piksel maka akan menghasilkan gambar yang lebih halus / realitas.

Cahaya adalah bentuk radiasi elektromagnetik, suatu fluktuasi medan listrik dan magnetik yang bergerak melalui ruang sebagai gelombang bergerak elektromagnetik. Spektrum gelombang ini termasuk gelombang radio, inframerah, cahaya tampak, ultraviolet, sinar-x, dan sinar gamma. (Madenda, 2015).

$\begin{array}{ccr}\text { Sinar } X & \text { adalah gelombang } \\ \text { elektromagnetik } & \text { yang } & \text { panjang }\end{array}$ gelombangnya berkisar antara 100 sampai $0.01 \mathrm{~nm}$. Sinar ini dihasilkan oleh transisi elektron dari satu lintasan ke lintasan lain yang energinya lebih rendah. Karena daya tembusnya sangat besar sehingga dapat menembus berbagai macam benda, maka sering digunakan untuk melihat gambar bagian dalam suatu obyek. (Supurwoko dan Sarwanto, 2010).

Gelombang cahaya tampak yang tertangkap oleh sel-sel cone dan rod dalam retina mata disampaikan ke syaraf visual otak dan membangkitkan berbagai sensasi warna. Sensasi warna ini secara praktis telah didefinisikan oleh CIE (Commission Internationale de l'Eclairage atau Internasional Commission on Illumination). Berdasarkan pada berbagai sensasi ini dan dengan menggunakan hasil akuisisi sensor warna, selanjutnya dikembangkan bergbagai ruang warna. (Madenda, 2015).

$\begin{array}{ccc}\text { Ruang warna dikembangkan } & \end{array}$ menghitung dan memvisualisasikan informasi warna sehingga dapat memudahkan komputer atau sistem digital lainnya untuk memproses infromasi warna dan membedakan warna seperti halnya sistem visual manusia. (Madenda, 2015).

Ada sekitar 10 ruang warna yang sering digunakan dalam pengolahan citra digital yaitu: RGB, CMYK, HSL, HSV,
CIELab, CIE, LCH, HCL, Yuv, YCbCr, dan YPbPr. (Madenda, 2015).

Yang dimaksud dengan tepi (edge) adalah perubahan nilai intensitas derajat keabuan yang mendadak (besar) dalam jarak yang singkat. Perbedaan intensitas inilah yang menampakkan rincian pada gambar. Tepi biasanya terdapat pada batas antara dua daerah berbeda pada suatu citra. Tepi dapat diorientasikan dengan suatu arah, dan arah ini berbeda-beda tergandung pada perubahan intensitas. (Munir, 2004), seperti pada gambar 2 .

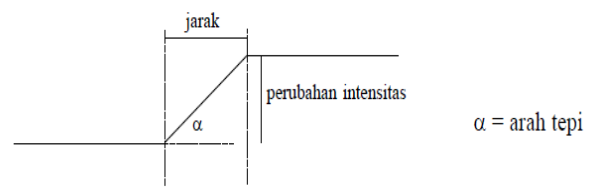

\section{Gambar 2. Bentuk tepi pada citra}

Tepi (edge) didefinisikan sebagai perubahan intensitas grey-level secara mendadak, dalam jarak yang singkat. Ada tiga macam tepi (edge) yang sering muncul di dalam citra digital: tepi curam, tepi landai, dan tepi yang mengandung noise. (Fadlisyah, 2008), seperti pada gambar 3.

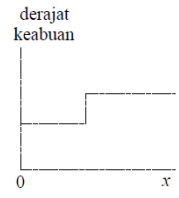

(a) Tepi curam

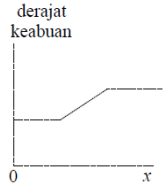

(b) tepi landai

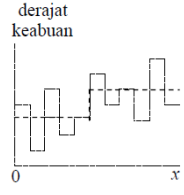

(c) tepi curam dengan derau

\section{Gambar 3. Jenis-jenis tepi citra}

Filtering adalah suatu proses di mana diambil sebagain sinyal dari frekuensi tertentu dan membuang sinyal pada frekuensi yang lain. Filtering pada citra juga menggunakan prinsip yang sama, yaitu mengambil fungsi citra pada frekuensifrekuensi tertentu dan membuang fungsi citra pada frekuensi-frekuensi tertentu. (Basuki, 2005).

Filtering spasial linier merupakan filtering yang dilakukan dengan operasi linear berupa konvolusi antara area lokal 
suatu sel bitmap dengan kernel. Pada proses filtering diperlukan sebuah filter $\mathrm{g}(\mathrm{x}, \mathrm{y})$ berupa matriks berukuran $\mathrm{m} x \mathrm{n}$, pada umumnya matriks yang digunakan adalah matriks berukuran $3 \times 3$ yang tiap-tiap sel-sel nya berisi nilai bobot. (Mulyana, 2017).

Sobel dan Prewitt masing-masing mengembangkan sebuah operator dengan mengunakan filter perata dan fungsi turunan perataan citra. Operator ini ditunjukkan agar dapat melakukan perataan atau minimalisasi noise oleh filter perata dan sekaligus melakukan pendeteksian tepi citra. Pemilteran dilakukan secara parsial dengan arah yang berlawanan dengan arah fungsi turunan pertama. Bila filter dilakukan dalam arah y maka turunan pertama dari hasil filter dilakukan dalam arah x. (Madenda, 2015).

Sebaliknya, turunan pertama arah $\mathrm{x}$ akan diikuti oleh pemilteran arah $\mathrm{y}$. Turunan pertama yang digunakan oleh Sobel dan Prewitt adalah antara dua titik $(\mathrm{x}+1, \mathrm{y})$ dan $(\mathrm{x}-1, \mathrm{y})$ serta $(\mathrm{x}, \mathrm{y}+1)$ dan $(\mathrm{x}, \mathrm{y}-$ 1). Sehingga, bila diuraikan dalam bentuk matriks (operator Sobel diberi notasi S, operator Prewitt diberi anotasi P) diperoleh, (Madenda, 2015), seperti pada gambar 4.

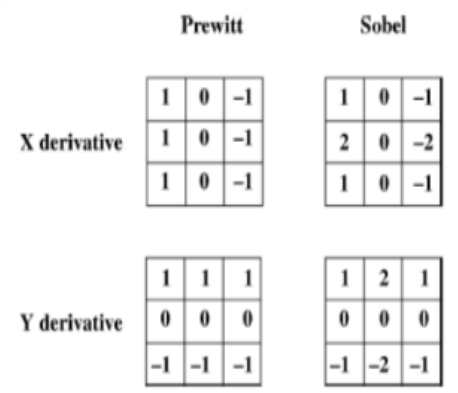

\section{Gambar 4. Nilai filter Sobel \& Prewitt}

Dari kedua operator ini terlihat bahwa Prewitt menggunakan filter rata-rata dengan semua elemnnya bernilai 1 , dengan asumsi bahwa tiga elemen/piksel kolom atau baris memberikan kontribusi intensitas yang sama pada titik di mana gradien itu dihitung. Sementara Sobel menggunakan filter di mana pada posisi titik tengah dari elemen matriknya bernilai 2 sedangkan tetangganya bernilai 1, dengan asumsi berdasarkan jarak antara piksel tetangga bahwa semakin menjauh piksel tetangga dari titik perhitungan maka semakin kecil kontribusi intensitasnya. Selain itu, asumsi ini dapat meningkatkan intensitas tepi yang dihasilkan. (Madenda, 2015).

Pada penelitian ini menggunakan filter Sobel dan Prewitt, untuk menampilkan bagian tepi (sisi) dari suatu citra atau mempertegas bagian dari suatu citra yang berupa garis. Sehingga bagian tepi atau bagian citra yang berbentuk garis akan dianalisis oleh pengguna data citra untuk menarik suatu kesimpulan sesuai dengan kebutuhan.

Pada penelitian ini di desain sebagai berikut:

1. Untuk meningkatkan (mempertegas) sisi-sisi / tepi dari citra masukan.

2. Citra masukan berupa citra dari hasil x-ray akan dikenakan proses grayscalle (membuat citra hitam putih).

3. Dari citra masukan akan dikenakan proses filter Sobel dan filter Prewitt.

4. Dua filter ini sudah memadai untuk menghasilkan tepi-tepi dari citra masukan yang meliputi sumbu $\mathrm{x}$ (sisi $\mathrm{x}$ ) dan sumbu y (sisi y) pada suatu citra masukan dan menghasilkan citra keluaran sesuai dengan filter yang dikenakan pada citra masukan.

5. Hasil percobaan akan dicatat dan disimpulkan persentase keberhasilan untuk mempertegas tepi-tepi dari citra dengan filter Sobel dan Prewitt. 


\section{Identifikasi Masalah}

Dalam dunia medis, penggunaan data hasil $\mathrm{x}$-ray sangat penting, terkadang hasil keluaran dari $\mathrm{x}$-ray agak samar (kabur). Terkadang untuk dasar analisis medis diperlukan tepian dari objek x-ray. Misalkan untuk mempertegas tepian citra $\mathrm{x}$ ray berupa keretakan (patah) tulang. Untuk keperluan tersebut pengolahan citra khususnya dibidang deteksi tepi dapat membantu untuk mempertegas tepian citra pada retakan/patah tulang dari hasil citra $\mathrm{x}$ ray.

\section{Tujuan dan Manfaat Penelitian}

Tujuan dari penelitian ini adalah untuk menghasilkan apliksi (software) yang digunakan untuk menampilkan tepi dari suatu citra yang dikenal dengan deteksi tepi. Deteksi tepi dengan filter frekuensi tinggi (High Pass Filter) digunakan untuk meningkatkan tepi dari suatu citra. Aplikasi yang dihasilkan digunakan untuk analisis citra $\mathrm{x}$-ray pada patah tulang, keretakan tulang pada usia manula (lanjut usia). Manfaat yang didapatkan dengan adanya aplikasi ini untuk membantu meningkatkan sisi-sisi (tepi) dari keretakan, patah tulang, sehingga mendapatkan beberapa sumber data analisis untuk pengambilan suatu kesimpulan.

\section{METODOLOGI PENELITIAN}

Pada proses analisis $\mathrm{X}-\mathrm{ray}$ diperlukan proses untuk membuat citra hitam putih (grayscalle) dari citra retakan tulang, atau patah tulang. Pada penelitian ini dilakukan penyusunan metode untuk citra masukan dari citra $\mathrm{x}$-ray hasil dari foto rontegn. Metode disusun dengan memanfaatkan operasi dasar penglohan citra seperti grayscalling untuk menghasilkan citra hitam putih, filtering untuk deteksi tepi, filter yang digunakan dalam hal ini adalah filter Sobel dan Prewitt.

Tahap I mengimplementasikan filter Sobel pada program. Tahap II mengimplementasikan filter Prewitt pada program. Untuk lebih detailnya akan dibahas tiap tahapannya:

Tahap I Implementasi filter Sobel, pada tahap ini aplikasi membaca filter masukan dan melakukan filter dengan filter Sobel, selanjutnya aplikasi akan menampilkan citra keluaran.

Tahap II Implementasi filter Prewitt, pada tahap ini aplikasi membaca filter masukan dan melakukan filter dengan filter Prewitt, selanjutnya aplikasi akan menampilkan citra keluaran.

Prosedur penelitian yang digunakan seperti langkah-langkah pada gambar 5 dan gambar 6.

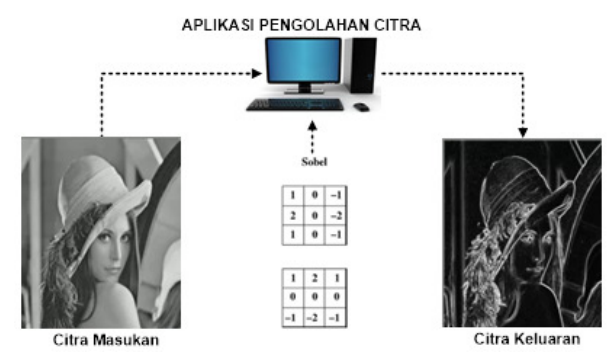

Gambar 5. Dengan filter Sobel

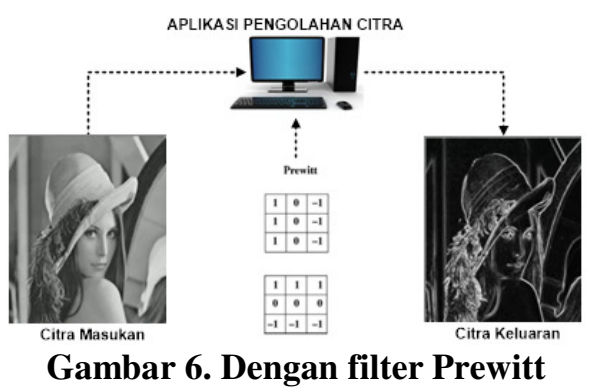

HASIL DAN PEMBAHASAN

Pada penelitian ini menggunakan dua filter yaitu filter Sobel dan filter Prewitt untuk mendapatkan sisi-sisi (tepi) dari citra.

\section{Membaca Citra}

Berikut cara membaca berkas citra digital seperti pada gambar 7.

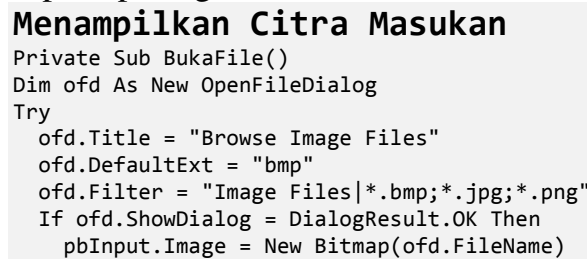




\author{
pbInput.SizeMode \\ PictureBoxSizeMode.StretchImage \\ End If \\ Catch ex As Exception \\ End Try \\ End Sub
}

\section{Gambar 7. Membaca berkas citra}

\section{Membuat Citra Grayscale}

Berikut cara membuat citra grayscale, seperti pada gambar 8 .

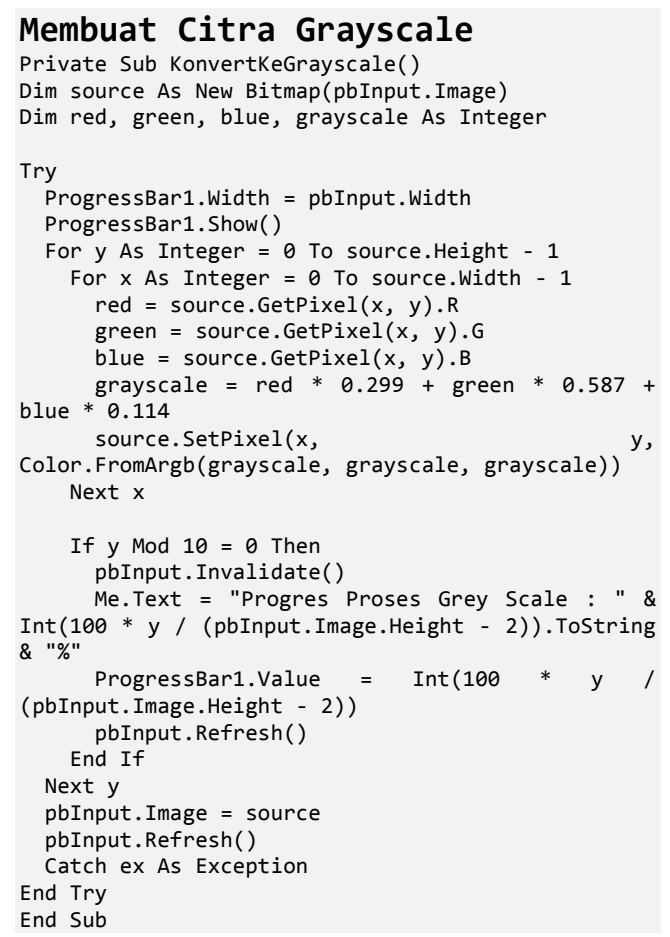

\section{Gambar 8. Citra grayscale}

\section{Filter Sobel}

Setelah menentukan citra masukan yang akan dikenakan filter Sobel, maka hasilnya seperti pada Gambar 5. Sebuah fungsi yang bekerja dengan filter Sobel dibuat, fungsi filter Sobel yang dibuat seperti pada gambar 9 .

\section{Fungsi Filter Sobel}

Public Function getSobelValue(ByVal neighbourList As Arraylist, ByVal maskType As String) As Integer Dim result As Integer $=0$

Dim sobelX As Integer $()=,\{\{-1,0,1\},\{-2,0$, $2\},\{-1,0,1\}\}$

Dim sobelY As Integer $()=,\{\{1,2,1\},\{0,0, \theta\}$, $\{-1,-2,-1\}\}$

Dim count As Integer $=0$

If (maskType.Equals("X")) Then

For $y$ As Integer $=0$ To 2

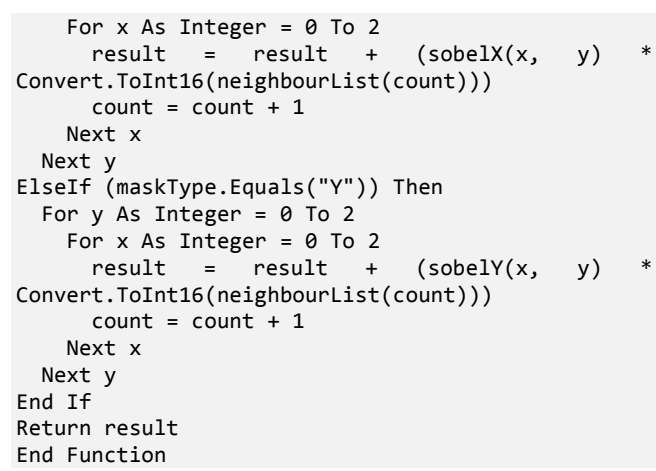

Gambar 9. Filter Sobel

\section{Filter Prewitt}

Setelah menentukan citra masukan yang akan dikenakan filter Prewitt, maka hasilnya seperti pada Gambar 6. Sebuah fungsi yang bekerja dengan filter Prewitt dibuat, fungsi filter Prewitt yang dibuat seperti gambar 10 .

\section{Fungsi Filter Prewitt}

Private Sub FilterSobel()

Dim source As New Bitmap(pbInput.Image)

Dim sobelResult As New Bitmap(pbInput.Image)

Dim sobelX, sobelY, magnitude As Integer

Dim neighbourList As ArrayList $=$ New ArrayList

Try

ProgressBar2. Width = pbInput. Width

ProgressBar2. Show()

For y As Integer $=0$ To source. Height -1

For $\mathrm{x}$ As Integer $=0$ To source. Width -1 neighbourList.Clear()

$y$, source)

neighbourList $=$ getThreeNeighbourList $(x$,

sobelX = getSobelValue(neighbourList,

"X")

"Y")

sobelY $=$ getSobelValue (neighbourList,

magnitude $=$ Math.Sqrt (Math.Pow $($ sobelX, 2)

+ Math.Pow(sobelY, 2))

If magnitude > 255 Then

magnitude $=255$

End If

sobelResult.SetPixel( $x$,

Color.FromArgb(magnitude, magnitude, magnitude))

Next $x$

If $y$ Mod $10=0$ Then

pbInput.Invalidate()

Me. Text = "Progres Proses Filter Sobel: "

$\& \operatorname{Int}(100 *$ y / (pbInput. Image. Height

2)). ToString \& "\%"

ProgressBar2.Value $=\operatorname{Int}(100 * y /$

(pbInput.Image.Height - 2)

pbInput.Refresh()

End If

pbOutput. Image $=$ sobelResult

Next y

pbOutput. Image $=$ sobelResult

pbOutput.SizeMode

PictureBoxSizeMode.StretchImage

Catch ex As Exception

End Try

End Sub 


\section{Gambar 10. Filter Prewitt}

Berdasarkan penelitian deteksi tepi yang sudah dilakukan, maka dapat diambil saran sebagai berikut: filter Sobel dan Prewitt berfungsi pada semua citra masukan dan menghasilkan citra keluaran dengan tepi-tepi citra lebih dipertegas sehingga memudahkan dalam analisis citra bagi yang membutuhkannya, tampilan aplikasi deteksi tepi ini seperti pada gambar 11 sampai dengan gambar 14. Pada sampel citra gambar 11 menggunakan citra patah tulang paha.

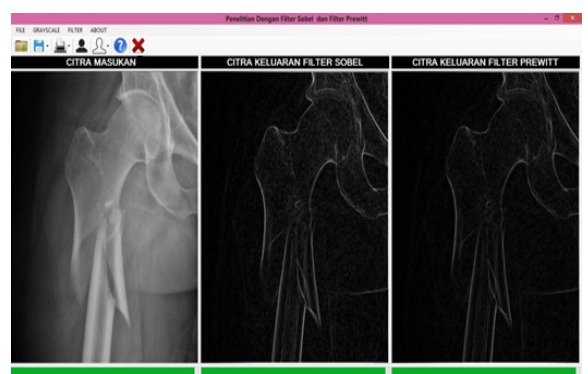

Gambar 11. Citra uji ke-1

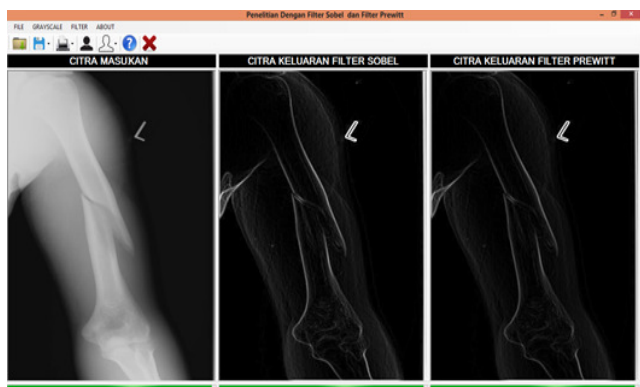

Gambar 12. Citra uji ke-2

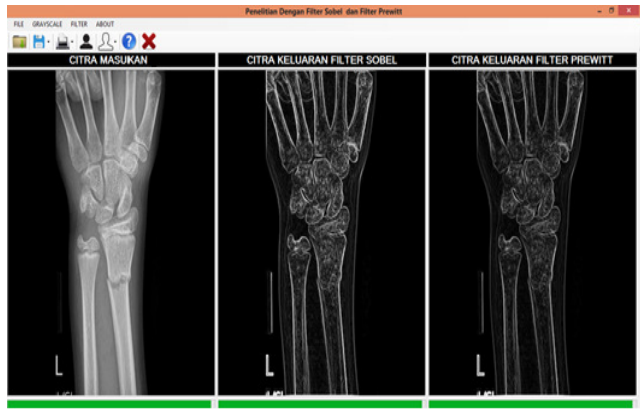

Gambar 13. Citra uji ke-3

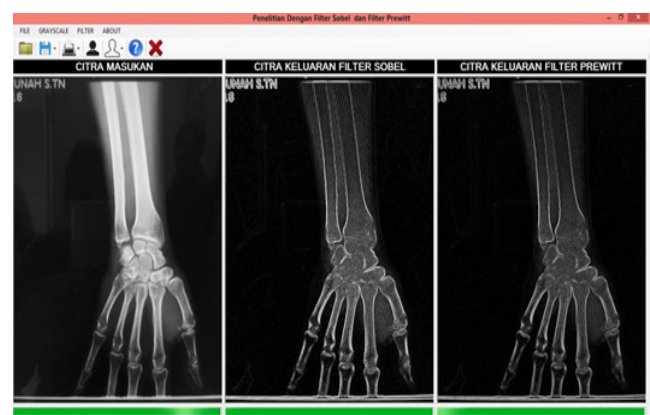

Gambar 14. Citra uji ke-4

Pada gambar 11 menggunakan sampel citra patah pada tulang lengan. Pada gambar 13 menggunakan sampel citra patah pada tangan. Pada gambar 14 menggunakan sampel citra memar pada pergelangan tangan.

\section{Tabel Uji Aplikasi}

Berikut adalah tabel uji aplikasi dengan beberapa data citra masukan hasil dari x-ray.

Pada sampel citra $\mathrm{x}$-ray 7 dan 8 dapat mempertegas retakan (patahan) pada tulang. Pada sampel citra $\mathrm{x}$-ray 9 keretakan (patahan) pada tulang tangan kurang terlalu tegas (kurang optimal) hal ini dikarenakan kondisi hasil $\mathrm{x}$-ray dimana kontras yang dihasilkan antara tepian patahan dan jaringan otot memiliki kontras yang hampir sama. Sehingga filter Sobel maupun Prewitt tidak dapat menampilkan tepian yang tegas (kuat).

Tabel 1. Contoh Tabel

\begin{tabular}{|c|c|c|c|c|c|c|}
\hline No & $\begin{array}{c}\text { Berkas } \\
\text { Citra } \\
\text { X-Ray }\end{array}$ & Usia & $\begin{array}{r}\text { J.K } \\
\text { ela } \\
\mathrm{mi} \\
\mathrm{n}\end{array}$ & Kondisi & Sobel & Prewitt \\
\hline 1 & $\begin{array}{l}\text { X-ray } \\
\text { tulang } \\
\text { paha }\end{array}$ & 60 & $\mathrm{~W}$ & Patah & Ok & Ok \\
\hline 2 & $\begin{array}{l}\text { X-ray } \\
\text { tulang } \\
\text { lengan }\end{array}$ & 65 & $\mathrm{P}$ & Patah & Ok & Ok \\
\hline 3 & $\begin{array}{l}\text { X-ray } \\
\text { tulang } \\
\text { tangan }\end{array}$ & 70 & $\mathrm{~W}$ & Patah & $\begin{array}{l}\text { Kurang } \\
\text { optimal }\end{array}$ & $\begin{array}{l}\text { Kurang } \\
\text { optima } \\
\text { lama }\end{array}$ \\
\hline 4 & $\begin{array}{l}\text { x-ray } \\
\text { tulang } \\
\text { tangan }\end{array}$ & 55 & $\mathrm{P}$ & Normal & $\begin{array}{l}\text { Tidak } \\
\text { menam } \\
\text { pilkan } \\
\text { retakan. } \\
\text { Ok }\end{array}$ & $\begin{array}{l}\text { Tidak } \\
\text { menam } \\
\text { pilkan } \\
\text { retakan } \\
\text { Ok }\end{array}$ \\
\hline
\end{tabular}

Pada sampel citra $\mathrm{x}$-ray dengan kondisi tulang normal pada gambar 10 , operator Sobel dan Prewitt tidak bekerja 
optimal (Ok) yaitu tidak menampilkan keretakan (tepi).

\section{SIMPULAN}

Berdasarakan penelitian deteksi tepi yang sudah dilakukan ini, maka dapat diambil kesimpulan:

1. Deteksi tepi yang dilakukan dengan operator Sobel memberikan tepi yang lebih tegas (kuat) sedangkan pada operator Prewitt agak kelihatan lebih kabur.

2. Kedua operator ini sama-sama dapat menampilkan tepi dari citra masukan berupa keretakan pada tulang dengan sampel citra $\mathrm{x}$-ray sebagai analasis lebih lanjut.

3. Pada kasus tertentu operator Sobel dan Prewitt kurang optimal menampilkan tepi dari keretakan tulang.

\section{DAFTAR PUSTAKA}

[1] Adlakha, D., Adlakha, D., and Tanwar, R., 2016. Analytical Comparison between Sobel and Prewitt Edge Detection Techniques, International Journal of Scientific \& Engineering Research, Volume 7, Issue 1.

[2] Bhat, Muzamil., 2014. Digital Image Processing, International Journal of Scientific \& Technology Research Volume 3, Issue 1.

[3] Basuki, Achmad., Palandi, Jozua F., 2005. Pengolahan Citra Digital Dengan Visual Basic, Graha Ilmu, Jakarta.

[4] Fadlisyah., Taufiq., Zulfikar., Fauzan., 2008. Pengolahan Menggunakan Delphi, Graha Ilmu, Jakarta.

[5] Kadir., Taufiq., Zulfikar., Fauzan., 2008. Pengolahan Menggunakan Delphi, Graha Ilmu, Jakarta.

[6] Kavita., Saroha, Ritika., Bala, Rajani., Siwach, Sunita., 2013. Review paper on Overview of Image Processing and
Image Segmentation, International Journal of Research In Computer Applications And Robotics, Vol.1 Issue.7, hal: 1-13.

[7] Madenda, Sarifudin., 2015. Pengolahan Citra \& Video Digital Teori, Aplikasi, dan Pemorgraman Menggunakan Matlab, Erlangga, Jakarta.

[8] Munir, Renaldi., 2004. Pengolahan Citra Digital Dengan Pendekatan Aloritmik, Penerbit Informatika, Bandung.

[9] Mulyana, Teady.M.S., 2017, Efek High Pass Filtering Dengan Koefesien Nol Pada Citra Biner, Jurnal Muara, Sains, Teknologi, Kedokteran, dan Ilmu Kesehatan, Vol 1, No. 1, hal 75-83.

[10] Srishti P, Verma, T., Prashant, 2016. Hybrid Filter of Sobel And Prewitt, International Journal of Latest Research in Engineering and Technology (IJLRET).

[11] Tania, Sheikh., and Rowaida, Raghad, 2016. A Comparative Study of Various Image Filtering Techniques for Removing Various Noisy Pixels in Aerial Image, International Journal of Signal Processing, Image Processing and Pattern Recognition Vol.9, No.3, hal.113-124.

[12] Supurwoko., Sarwanto., 2010. Deteksi Sisi Citra Tomografi Sinar-X Menggunakan Operator Laplace, Seminar Nasional Biologi FKIP UNS, hal 213-219.

[13] Patidar, Pawan Kumar., Lalit., Singh, Baldev., Bagaria, Gaurav., 2014. Image Filtering using Linear and Non Linear Filter for Gaussian Noise, International Journal of Computer Applications, Volume 93 - No.8, hal 29-34.

[14] Putra, Darma., 2010. Pengolahan Citra Digital, Penerbit Andi, Yogyakarta. 